\title{
PENGEMBANGAN MEDIA KIJANK (KOMIK INDONESIA, JAWA, DAN AKSARA JAWA) PEMBELAJARAN BAHASA JAWA KELAS 5 SEKOLAH DASAR
}

\author{
Nurhasanah, Arif Budi Wurianto, Bustanol Arifin \\ Madrasah Ibtidaiyah Cemorokandang Jl. Sampurna No. 77 \\ Email : nurhasanah90788@gmail.com
}

\begin{abstract}
This research aim to produce a form of media "KIJANK( comics Indonesia, Java, and Java Script)" that interesting to help student to read java script. This study uses the research of R \& D (Research and Development) and the type of research is the development of research. As a source of data, selected 5th grade students of SDN Kedungrejo 1 2014/2015 school year, amounting to 10 students. And 5th grade students of MI Cemorokandang 2014/2015 school year, amounting to 40 students. This study was conducted in August 2014 in two phases, namely the study of small group and large group study. The results showed that the use of media KIJANK can assist students in learning to read Java script. This is evidenced by the results of validation of some experts such as, media expert validation by $84.6 \%$, materials expert validation by $94 \%$, and validation of expert fields of study by $98 \%$. While a small group of trial results showed that $89 \%$ of learning to use the media KIJANK in learning the Java language has received a positive response from students and very valid, also feasible to use for learning. And the test results indicate that a large group $94.5 \%$ of learning to use the media KIJANK (Comic Indonesia Java and Java script) in learning the Java language is very feasible and valid to use as a learning medium. The results of this study, learning media KIJANK recommended to be used as a reference for the preparation of teaching and tutoring programs as well as develop other learning media that can support the learning process. Reading sklils of java letter, such as wingnyan (h), layar (/), cecek (=), and pangku (\) now is on the decline, so the need for efforts to increase through the use of instructional media. The result of needs analysis through questionnaires and observation showed that $60 \%$ of the 40 students are not able to read java letter, so they have difficulty when doing the exam.
\end{abstract}

\begin{abstract}
Abstrak: Kemampuan membaca huruf Jawa, seperti wignyan $(h)$, layar $(/)$, $\operatorname{cecek}(=)$, dan pangku ( $($ ) saat ini sudah mulai mengalami penurunan, sehingga perlu adanya upaya peningkatan melalui pemanfaatan media pembelajaran. Hasil analisis kebutuhan melalui penyebaran angket dan observasi menunjukkan bahwa $60 \%$ dari 40 siswa tidak mampu membaca huruf Jawa, sehingga mengalami kesulitan ketika mengerjakan soal ujian. Penelitian ini bertujuan untuk menghasilkan bentuk media "KIJANK (komik Indonesia, Jawa dan aksara Jawa)" yang menarik untuk membantu siswa membaca aksara Jawa. Penelitian ini menggunakan penelitian R\&D (Research and Development) dan jenis penelitian yang dilakukan adalah penelitian pengembangan. Sebagai sumber data, dipilih siswa kelas 5 SDN Kedungrejo 1 tahun ajaran 2014/2015 yang berjumlah 10 siswa. Dan siswa kelas 5 MI Cemorokandang tahun ajaran 2014/2015 yang berjumlah 40 siswa. Penelitian ini dilakukan pada bulan Agustus 2014 dalam dua tahap, yaitu penelitian kelompok kecil dan penelitian kelompok besar. Hasil penelitian menunjukkan bahwa penggunaan media KIJANK dapat membantu siswa dalam belajar membaca aksara Jawa. Hal ini dibuktikan oleh hasil validasi beberapa ahli antara lain, validasi ahli media sebesar $84.6 \%$, validasi ahli materi sebesar $94 \%$, dan validasi ahli bidang studi sebesar 98\%. Sementara hasil uji coba kelompok kecil menunjukkan bahwa $89 \%$ pembelajaran menggunakan media KIJANK dalam pembelajaran bahasa Jawa ternyata mendapat respon positif dari siswa dan sangat valid serta layak digunakan untuk pembelajaran. Dan hasil uji coba kelompok besar menunjukkan bahwa $94.5 \%$ pembelajaran menggunakan media KIJANK (Komik Indonesia Jawa dan Aksara Jawa) dalam pembelajaran bahasa Jawa sangat layak dan valid digunakan sebagai media pembelajaran. Hasil penelitian ini, media pembelajaran KIJANK disarankan untuk dipergunakan sebagai
\end{abstract}


acuan penyusunan program pengajaran dan bimbingan belajar serta mengembangkan media pembelajaran lain yang dapat mendukung proses pembelajaran.

Kata Kunci : maningkatkan, membaca, huruf Jawa, KIJANK

\section{PENDAHULUAN}

Bahasa daerah merupakan salah satu unsur budaya yang mempunyai peranan penting, antara lain sebagai "lambang kebanggaan daerah, lambang identitas daerah, dan alat penghubung di dalam keluarga dan masyarakat daerah" kedudukan dan fungsi bahasa daerah dan bahasa asing menurut Ariyanty (diakses tanggal 16 juni 2014). Hal ini diperkuat dengan adanya UndangUndang Dasar (UUD) 1945 bab XIII mengenai pendidikan dan kebudayaan pasal 32 ayat 2 yang berbunyi "Negara menghormati dan memelihara bahasa daerah sebagai kekayaan budaya nasional". Dengan demikian, bahasa daerah merupakan sebuah pendukung dari bahasa Indonesia yang keberadaannya didukung oleh Negara.

Masuknya mata pelajaran bahasa daerah pada tingkat Sekolah Dasar mendorong guru untuk lebih kreatif dalam menyampaikan materi. Aksara Jawa merupakan salah satu cabang dari mata pelajaran bahasa daerah. Pada umumnya pembelajaran yang dilakukan tanpa menggunakan media. Sedangkan, jika guru lebih banyak berceramah maka konsentrasi siswa akan mudah terpecah dengan hal lainnya yang lebih menarik. Dewasa ini, guru mengalami kesulitan dalam menyampaikan materi membaca huruf Jawa sehingga waktu yang telah digunakan kurang maksimal selama pembelajaran. Pola pembelajaran ini bertolak belakang dengan kondisi ideal dari sebuah pembelajaran. Seorang guru harus mampu menciptakan suasana pembelajaran yang menarik dan menyenangkan sehingga siswa bersedia untuk belajar dengan baik sesuai petunjuk dan arahan guru.

Hasil analisis kebutuhan dengan penyebaran angket dan observasi, nilai bahasa Jawa Sekolah Dasar kelas 5 semester 1 me- ngalami penurunan terutama pada materi membaca aksara Jawa dapat menimbulkan berbagai spekulasi mengenai proses pembelajaran yang telah dilaksanakan. $60 \%$ siswa dari 40 siswa tidak mampu membaca aksara Jawa, selain itu terbatasnya media pembelajaran yang digunakan juga merupakan salah satu faktor penyebab kurang berhasilnya penyampaian materi membaca huruf dengan baik, sehingga mengalami kesulitan ketika mengerjakan soal ujian. Sebagaimana diketahui jika gemar membaca maka akan memperoleh ilmu yang banyak, sebab buku merupakan gudang ilmu.

Untuk mengefektif dan efisiensi suatu proses pembelajaran membutuhkan sebuah media yang sesuai dengan materi dan minat siswa. Menurut (Daryanto, 2013:6) "media pembelajaran merupakan segala sesuatu yang dapat digunakan untuk menyalurkan pesan (bahan pembelajaran) sehingga dapat merangsang perhatian, minat, pikiran dan perasaan siswa dalam kegiatan belajar untuk mencapai tujuan belajar". Adanya sebuah media pembelajaran akan membantu guru dalam menyampaikan materi dan siswa akan lebih mudah memahami materi yang telah disampaikan. Sehingga dengan adanya media guru dapat berperan sebagai fasilitator, mediator dan pembimbing siswa selama proses pembelajaran.

Peranan bahasa daerah dalam kurikulum tahun 2013 menurut Permendikbud No. 67 tahun 2013 yaitu sebagai muatan lokal dapat diajarkan secara terintegrasi dengan mata pelajaran seni budaya dan prakarya atau diajarkan secara terpisah apabila merasakan perlu untuk memisahkannya. Satuan pendidikan dapat menambah jam pelajaran per minggu sesuai dengan kebutuhan satuan pendidikan tersebut. Berdasarkan uraian diatas, maka bisa dikatakan bahwa pelajaran bahasa daerah tidak dihilangkan 
dalam kurikulum, namun diintegrasikan untuk mencapai tujuan pendidikan.

Komik merupakan buku bacaan yang paling diminati siswa. Oleh sebab itu, dibutuhkan media pembelajaran yang berupa komik. Pengembangan media KIJANK (komik Indonesia, Jawa dan aksara Jawa) pada pembelajaran bahasa daerah kelas 5 Sekolah Dasar, dapat dijadikan sebuah alternatif untuk membantu kemampuan siswa membaca aksara Jawa. Selain itu KIJANK juga mengandung nilai-nilai karakter yang dapat membentuk siswa menjadi pribadi yang baik.

\section{METODE PENELITIAN}

Model pengembangan yang digunakan dalam penelitian ini adalah model prosedural. Model prosedural adalah model yang bersifat deskriptif, yaitu menggariskan langkah-langkah yang harus diikuti untuk menghasilkan produk. Penelitian pendidikan dan pengembangan lebih dikenal dengan istilah Research \& Development (R\&D) dikembangkan Borg \& Gall. Menurut (Borg \& Gall dalam Punaji, 2010:215) penelitian pengembangan merupakan suatu proses yang dipakai untuk mengembangkan dan memvalidasi produk pendidikan.

Menurut Sugiyono (2013:409) secara prosedural langkah-langkah penelitian pengembangan (R\&D) dari model Borg and Gall (1983) adalah sebagai berikut:

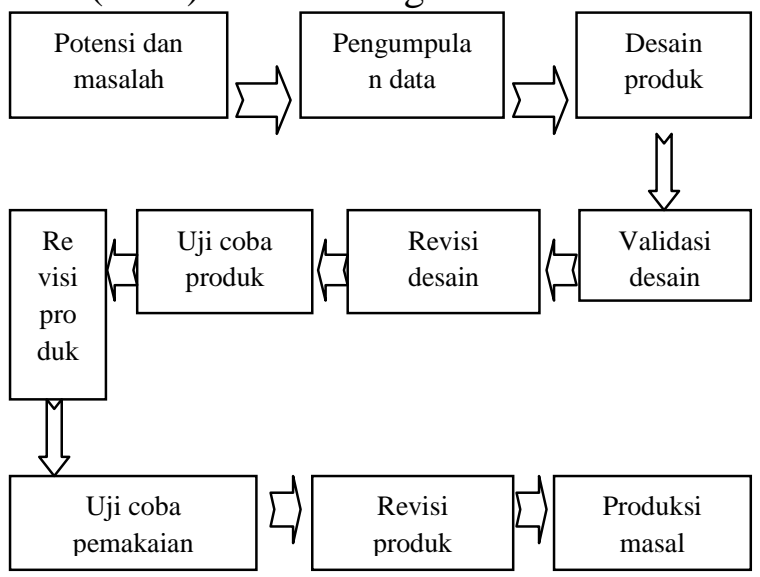

Gambar 3.1 Langkah-langkah penelitian dan pengembangan/Research and Development (R\&D) dari model Borg and Gall (1983) diadopsi dari Sugiyono

\section{HASIL DAN PEBAHASAN}

\section{Bentuk Media KIJANK}

Komik yang disajikan disini berbeda dengan komik-komik yang sudah beredar dipasaran, karena KIJANK memiliki dua bahasa dan satu tulisan, yaitu bahasa Indonesia, Jawa dan Aksara Jawa. Media KIJANK terdapat beberapa bagian, yaitu ada bagian awal, isi, dan penutup. Pada bagian awal terdapat cover, manfaat membaca KIJANK dan perkenalan tokoh cerita. Sementara pada bagian isi terdapat sebuah cerita yang manarik. Dan pada bagian penutup terdapat sinopsis. Untuk melengkapi komik dan membantu siswa dalam membaca huruf Jawa maka pada halaman belakang komik dilampirkan aksara Jawa dan aksara swara, aksara murdha dan wilangan serta sandhangan.

KIJANK merupakan komik yang full color memiliki panjang $22 \mathrm{~cm}$ dan lebar 15 $\mathrm{cm}$. Selain itu KIJANK dicetak dengan menggunakan kertas art paper 120 gram, kecuali halaman sampul menggunakan kertas art paper 240 gram. Perpaduan gambar dan warna yang menarik akan menambah keindahan KIJANK. Selain itu, balon kata pada komik yang dapat dibuka untuk mengetahui arti tulisan akan semakin menambah rasa penasaran dan ketertarikan siswa membaca KIJANK.

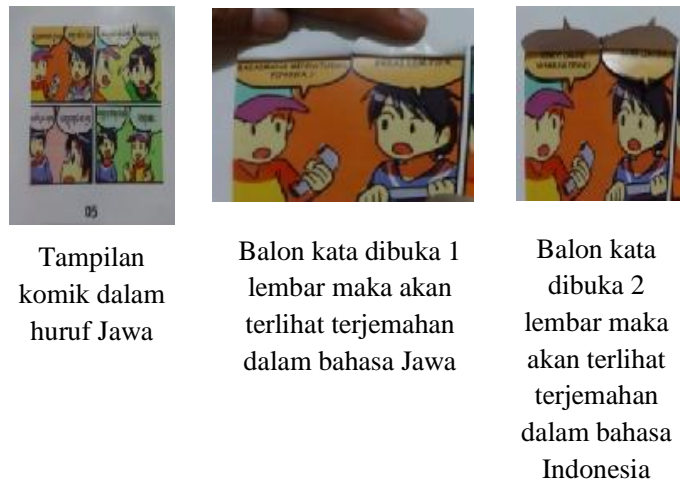

\section{HASIL PENELITIAN}

Selama proses pembelajaran bahasa Jawa berlangsung, siswa cepat merasa 
bosan dan kurang aktif sehingga banyaknya siswa yang ramai didalam kelas, selain itu rendahnya minat baca dan kurang tertariknya siswa terhadap mata pelajaran bahasa Jawa juga memicu adanya kelas yang tidak kondusif. Jika dilihat dari segi pengajar, pembelajaran masih berpusat pada guru sehingga guru lebih aktif dan siswa cenderung pasif. Selain itu, guru juga kurang mampu dalam membuat suatu media pembelajaran. Media pembelajaran yang digunakan untuk pembelajaran bahasa Jawa masih terbatas pada media dua dimensi seperti papan tulis, buku, LKS dan poster serta kartu aksara Jawa. Padahal dengan menggunakan sebuah media akan menambah antusias siswa belajar bahasa Jawa.

Metode yang sering digunakan dalam mata pelajaran bahasa Jawa adalah metode ceramah, tanya jawab, dan diskusi. Untuk itu dibutuhkan media yang dapat meningkatkan motivasi belajar siswa, selain itu media tersebut harus efektif, mengaktifkan dan bermanfaat bagi siswa.

\section{Analisis kebutuhan}

Kurangnya minat siswa untuk menghafalkan huruf Jawa menjadi kendala sebab dalam membaca huruf Jawa terdapat perbedaan lafal yang cukup sulit. Sehingga siswa mengalami kesulitan jika membaca huruf Jawa tanpa dipandu oleh guru. Sekitar $60 \%$ dari jumlah siswa tidak bisa membaca huruf Jawa. Dalam pembelajaran guru menggunakan stratagi menghafal dan mengingat serta pendekatan yang digunakan ketika pembelajaran adalah pendekatan konstruktivisme. Untuk melakukan penilaian membaca, guru memberikan tugas pada siswa untuk membaca kalimat dengan huruf Jawa dan sebaliknya. Disamping itu sekolah belum memiliki buku bacaan huruf Jawa. Padahal media itu sangat penting untuk menunjang proses pembelajaran namun guru juga belum pernah menggunakan media komik sebagai pembelajaran khususnya bahasa Jawa. Komik bisa dijadikan sebagai alat komunikasi dalam pembelajaran karena dapat mendorong semangat siswa untuk belajar. Kemungkinan keberhasilan menggunakan media komik dalam belajar membaca huruf Jawa cukup besar karena siswa merasa tertarik minatnya untuk membaca, segera ingin tahu isi ceritanya. Buku yang digunakan untuk mendukung proses pembelajaran bahasa Jawa adalah buku paket dan LKS. Sementara siswa kurang berminat untuk membaca buku tersebut. Media itu sangat penting bagi proses pembelajaran. Namun guru juga belum pernah menggunakan komik sebagai media pembelajaran walaupun telah diketahui bahwa komik merupakan bacaan yang diminati siswa terutama dalam bagian gambarnya.

\section{Validasi \\ Validasi ahli media pembelajaran}

Setelah dilakukan revisi maka penulis melakukan validasi dan memperoleh penilaian bahwa secara keselurahan media KIJANK mempunyai kelebihan antara lain gambar tidak mengganggu materi, media aman dan mudah digunakan, dan bersifat fleksibel (mudah dipindahkan dan dibawa). Angket validasi media setelah direvisi tidak mendapatkan saran maupun komentar dari ahli media. Adapun hasil yang diperoleh dari validasi ahli media pembelajaran sesudah revisi adalah memperoleh nilai total sebanyak 55 skor dan menunjukkan presentase $84,6 \%$. Skor presentase validasi media (70\%-84\%) maka media yang dikembangkan tersebut valid dilihat dari segi pewarnaan (colour), pemakaian kata atau bahasa (text layout), grafis (graphics), dan desain (interface), serta tata letak (layout).

\section{Validasi ahli materi bahasa Jawa}

Tahap revisi media pada validasi kedua, secara keseluruhan diperoleh hasil yaitu media dapat digunakan secara individu maupun kelompok, penulisan sangat sesuai dengan tata bahasa, konsep materi benar dan sesuai dengan SKKD, serta 
media mudah digunakan dan pengguna tidak akan merasa bosan. Pada revisi ini ahli materi tidak memberikan komentar maupun sarannya. Berdasarkan hasil validasi ahli materi, diperoleh skor total 47 dengan tingkat presentase 94\%. Kualitas media diperoleh baik sekali dan layak digunakan sebagai media pembelajaran.

\section{Validasi ahli bidang studi}

Berdasarkan validitas ahli bidang studi dalam penelitian ini menunjukkan bahwa $98 \%$ media KIJAK sudah layak digunakan sebagai media pembelajaran. Media ini memenuhi kriteria layak dari segi pembelajaran, isi materi, interaksi dan umpan balik.

\section{Uji coba kelompok kecil}

Hasil kegiatan uji coba kelompok kecil dengan menggunakan media KIJANK siswa antusias dan tertarik menggunakan media tersebut, hampir semua siswa aktif karena adanya media KIJANK siswa menjadi termotivasi dalam proses pembelajaran bahasa Jawa, akan tetapi masih ada beberapa siswa yang pasif. Pembelajaran yang terpusat kepada siswa akan membuat siswa tidak merasa bosan selama proses pembelajaran. Beberapa siswa masih kurang paham tentang bagaimana cara penggunaan media KIJANK. Hasil respon siswa terhadap media dalam kelompok kecil diperoleh yaitu jumlah skor positif (YA) sebanyak $89 \%$ jika dikonversikan ke- dalam skala Sudjana, maka proses pembela- jaran menggunakan media KIJANK dalam pembelajaran bahasa Jawa ternyata mendapat respon positif dari siswa dan sangat valid serta layak digunakan untuk pembelajaran.

\section{Hasil uji coba kelompok besar}

Berdasarkan hasil pengamatan peneliti maka secara keseluruhan media dapat mengaktifkan siswa selama proses pembe- lajaran, dapat membantu siswa belajar membaca aksara Jawa, siswa merasa senang belajar menggunakan media KIJANK sehingga beberapa siswa ingin memilikinya. Pada saat uji coba kelompok besar juga masih terdapat kekurangan-kekurangan tersebut yaitu (1) kondisi kelas kurang kondusif karena siswa antusias menggunakan media (2) masih ada salah satu siswa yang masih kurang paham cara menggunakan media, dan (3) salah satu siswa masih ada yang pasif.

Hasil respon siswa terhadap kelompok besar diperoleh respon positif (YA) diperoleh sebanyak 378 atau $94.5 \%$ jika dikonversikan dalam skala Sudjana, maka proses pembelajaran menggunakan media KIJANK (Komik Indonesia Jawa dan Aksara Jawa) dalam pembelajaran bahasa Jawa sangat layak dan valid digunakan sebagai media pembelajaran.

\section{PEMBAHASAN}

Adapun hasil analisis kebutuhan secara keseluruhan yang diperoleh di SDN Kedungrejo I dan MI Cemorokandang mengenai pembelajaran bahasa Jawa dapat diuraikan bahwa proses pembelajaran bahasa Jawa sudah sesuai dengan prosedur kurikulum KTSP. Peserta didik kurang menyukai pelajaran bahasa Jawa karena mereka menganggap bahwa pelajaran tersebut sangat membosankan. Hal ini yang mendasari peserta didik mengalami kesulitan dalam memahami materi membaca aksara Jawa.

\section{SIMPULAN}

Penelitian ini termasuk jenis penelitian pengembangan untuk menghasilkan suatu produk yang berupa media pembelajaran bahasa Jawa yaitu KIJANK (komik Indonesia Jawa dan Aksara Jawa) untuk kelas 5 Sekolah Dasar. Materi yang dikembangkan dalam media ini membaca kalimat berhuruf Jawa yang menggunakan sandhangan panyigeg wanda yang meliputi wig- 
nyan $(h)$, layar $(/)$, cecek $(=)$, dan pangku ( $)$.

Sesuai dengan uji kelayakan media pembelajaran ini dilakukan melalui beberapa tahap yaitu tahap pertama validasi desain media pembelajaran oleh ahli media pembelajaran menunjukkan presentase $84,6 \%$ dengan kriteria valid. Kemudian dilanjutkan dengan validasi dengan ahli materi pembelajaran bahasa Jawa kelas 5 Sekolah Dasar menunjukkan kriteria sangat valid $94 \%$. Tahap berikutnya yaitu validasi ahli bidang studi yang menunjukkan kriteria sangat valid yaitu $98 \%$.

Tahap selanjutnya adalah uji coba kelompok kecil sebanyak 10 siswa melalui angket respon siswa di SDN Kedungrejo I menunjukkan kriteria sangat valid yaitu $89 \%$. Pada tahap terakhir uji coba kelompok besar sebanyak 40 siswa kelas 5 MI Cemorokandang yang menunjukkan kriteria sangat valid yaitu $94.5 \%$. Kedua uji coba kelompok besar maupun kelompok kecil memperoleh hasil yang sangat valid atau sangat layak digunakan sebagai media pembelajaran bahasa Jawa kelas 5 Sekolah Dasar.

\section{DAFTAR PUSTAKA}

AH, Hujair Sanaky. 2011. Media Pembelajaran. Yogyakarta: Kaukaba.

Anonim. 2014. UUD 1945 \& GBHN. Palito Media.

Arsyad, Azhar. 2010. Media Pembelajaran. Jakarta: PT. Raja Grafindo Persada.

— . 2013. Media Pembelajaran. Jakarta: Rajawali Pers.

Asyhar,Rayandra. 2012. Kreatif Mengembangkan Media Pembelajaran. Jakarta: Referensi Jakarta.

Daryanto. 2012. Media Pembelajaran. Bandung: PT. Sarana Tutorial Nurani Sejahtera.

— . 2013. Media Pembelajaran. Yogyakarta: Gava Media.
Munadi, Yuhdi. 2013. Media Pembelajaran. Jakarta Selatan: Referensi (GP Press Group).

Nuviana,Intan. 2010. Belajar Membaca Tanpa Mengeja. PT Buku Kita: Jakarta.

Putra,Nusa. 2013. Research \& Development. Jakarta: Rajawali Pers.

Rahim, Farida. 2005. Pengajaran Membaca di Sekolah Dasar. Jakarta: Bumi Aksara.

Riyadi, Slamet. 1996. Ha-na-ca-ra-ka. Yayasan Pustaka Nusatama: Yogyakarta.

Rochkyatmo, Amir. 1996. Pelestarian dan Modernisasi Aksara Daerah. Jakarta: CV Putra Sejati Raya.

Sadiman, Arief S. 2010. Media pendidikan, Pengertian, Pengembangan, dan Pemanfaatannya. Jakarta: PT. Raja Grafindo Persada.

Sadiman, Arif dkk. 2012. Media Pendidikan. Jakarta: Pustekom Dikbud dan PT Raja Grafindo Persada.

Setiawan, Agus. 2010. Baca Kilat. PT. Gramedia Pustaka Utama: Jakarta.

Sudjana,Nana.1990. Penilaian Hasil Proses Belajar Mengajar. Bandung: Remaja Rosdakarya.

Sudjana. 1990. Media Pengajaran. Jakarta: Sinar Baru Algesindo.

Sugiyono. 2013. Penelitian Kualitatif, Kuantitaf, $R \& D$. Jakarta: Alfabeta.

Sukmadinata,Nana. 2007. Metode Penelitian Pendidikan. Bandung: PT Remaja Rosdakarya.

Sutikno, Sobry. 2013. Belajar Dan Pembelajaran. Jakarta: Holictica.

Sutyosari,Punaji. 2010. Metode Penelitian dan Pengembangan. Jakarta: Prenada Media Group.

Tarigan,Henry. 2008. Membaca Sebagai Suatu Keterampilan Berbahasa. Bandung: Angkasa

Yuliarti. 2011. Karakteristik Buku Cerita Anak yang Diminati Anak-anak Pengunjung Toko Buku Toga Mas. Malang: Universitas Negeri Malang 
Anonim. 2014. Aksara Jawa. (Online) http://id.wikipedia.org, diakses pada tanggal 27 Januari 2014.

Anonim. $2014 . \quad$ Komik. http://id.wikipedia.org, diakses pada tanggal 29 Januari 2014.

Ariyanti, Tholib. 2011. Kedudukan dan Fungsi Bahasa Daerah dan Bahasa Asing. (Online) http://Pendidikanmatematika2011.blog spot.com, diakses pada tanggal 16 Juni 2014.

Mustajab, Ade S. 2011. Jenis-Jenis Komik. (Online)http://pensilseni.wordpress.co m, diakses pada tanggal 27 Mei 2014.

Kementerian Pendidikan. 2013. Gambar Aksara Jawa. (Online) http://sumberbelajar.belajar.kemdikbud .go.id/katalogmedia/Kelas\%20Maya/S D/Kelas\%204/Muatan\%20Lokal/Rakh mat\%20Pamuji/Gambar/huruf\%20jawa .png, diakses tanggal 27 Mei 2014.

Sudrajat, Akhmad. 2014. Peraturan Menteri Pendidikan dan Kebudayaan No 67 Tahun 2013. (Online) http://akhmadsudrajat.wordpress.com, diakses pada tanggal 17 Juni 2014. 